\title{
Akciono istraživanje i predškolska vaspitna praksa
}

\author{
Jelena Stamatović \\ Univerzitet u Kragujevcu \\ jelena.stamatovic22@gmail.com
}

\author{
Lidija Zlatić \\ Univerzitet u Kragujevcu \\ Izlatic@ptt.rs
}

U radu se razmatraju mogućnosti primene akcionih istraživanja u predškolskom vaspitanju. Naglašava se razvojni karakter ove vrste istraživanja i funkcija unapređivanja vaspitne prakse. Potreba savremenog vrtića je usmerena na planiranje razvoja u skladu sa potrebama, a akciono istraživanje menja praksu i razvija je. Za realizaciju akcionog istraživanja neophodno je da vaspitači, praktičari poseduju kompetencije koje pretpostavlaju spremnost za drugačije promišljanje problema u vaspitnoj praksi, kao i refleksivni pristup vaspitnom procesu u praksi.

Ključne reči: akciona istraživanja, predškolska ustanova, refleksivna praksa, vaspitači

\section{Uvod}

Savremena gledišta akciona istraživanja uglavnom aktualizuju kao put unapređivanja vaspitne prakse. Mnogi pristupi njegovog određenju ovog ukazuju na to da pored menjanja prakse, menja se i uloga onoga ko realizuje istraživanje, praktičari su ti koji organizuju i sprovode istraživanje samostalno ili u timu (Galini i Efthymia 2010; Lee i Goh 2012; Maksimović 2012; Pešić 2004). Potreba savremene prakse u vaspitno-obrazovnim institucijama je usmerena na stalno menjanje i unapređivanje. Mnogi aktuelni problemi, svojstveni neposrednim situacijama u radu vaspitača mogu postati problemi i istraživačka pitanja koja praktičari rešavaju, istražuju, uvode novine i prate promene.

U predškolskim ustanovama koje teže promenama i kvalitetu za vaspitača nije dovoljno da bude samo korisnik rezultata istraživanja koje uglavnom realizuju profesionalni istraživači, već i oni sami moraju postati aktivni realizatori u procesu istraživanja u svom domenu rada. Svrha ovog rada je da se analizira mogućnost i adekvatnost primene akcionih istraživanaja u unapređivanju rada predškolskih ustanova i uloga vaspitača kao nosioca tih istraživanja i da se ponude novi izazovi za razmišljanje vaspitača praktičara. 


\section{Akciona istraživanja i vaspitna praksa}

Akciona istraživanja se najčešće povezuju sa menjanjem kvaliteta vaspitne prakse, pri čemu istraživači, praktičari, polaze od svojih specifičnih problema sa kojima se susreću u praksi (Maksimović i Banđur 2013; McNiff i Whitehead 2006). Ova istraživanja su usmerena i na razumevanja same prakse i procesa u njoj, ali istovremeno i doprinose unapređivanju i razvoju onih koji ga realizuje, jer u tom procesu tragaju za rešenjima postavljenih problema ili nerešenih situacija u praksi (Bognar 2009).

Lankshear i Knobel (2004) ističu da je cilj i svrha istraživača, praktičara usmerena u dva pravca: na poboljšanje osećaja praktičara o sopstvenoj profesionalnoj ulozi i identitetu i na to da istraživanja praktičara mogu doprineti boljoj i kvalitetnijoj praksi. Ono što se može apstrahovati iz različitih definicija akcionih istraživanja pokazuje da se ona zasnivaju na pristupu praksi kroz različite metode u radu i usmereni su na rad na promenama kroz različite oblike interakcije u grupi, timu, među generacijama ili samostalno. Akcionim istraživanjima se pokušavaju rešiti konkretni problemi sa kojima se praktičari suočavaju u svom radu sa decom, roditeljima, u lokalnoj zajednici, u vaspitnoj ustanovi. Time se menja njihova uloga u profesionalnom razvoju i razvoju kompetencija kao istraživača. Ishodi istraživanja vlastite prakse i pozitivne promene doprinose povećanju osećaja sopstvene vrednosti i samopouzdanja kod praktičara, vaspitača, takođe doprinose povećanju svesti vaspitača o realnim problemima u grupi, među decom i jačaju njihov pozitivan odnos prema refleksiji sopstvene prakse.

Savremeni trendovi u istraživanju praktičara, učitelja, nastavnika, vaspitača ukazuju da su ona često kvalitativna, da se bave istraživanjem vlastite prakse i time doprinose sopstvenom razvoju i pozitivnim promenama u vaspitnom procesu (Lankshear i Knobel 2004). Jasno je da akciona istraživanja imaju niz prednosti i da ona pružaju pomoć svima onima koji se bave vaspitnim procesima da sebe aktiviraju i doprinesu kvalitetu tih procesa, brizi za decu ali kroz istraživanje i procenjivanje sopstvene delatnosti u okviru tih procesa (McNiff i Whitehead 2006). Sam proces akcionih istraživanja se odlikuje višedimenzionalnim spiralnim pristupom koji ukazuje na spontanost u stvaralačkom i razvojnom procesu akcionih istraživanja (Bognar 2006; Maksimović 2010).

Mnogi autori koji su se bavili pitanjima realizacije akcionih istaživanja naglašavali su paricipativni karakter ove vrste istraživanja (Gojkov 2007; Park 1999; Petrović 2008). To podrazumeva da učesnici u socijalnoj situaciji koja se proučava nužno su i učesnici u svim fazama istraživanja. Ovakav pristup još odlikuje, pored participacije i angažovanost, demokratičnost i inkluziv- 
nost. Imajući u vidu kontekst predškolske ustanove u kome se može sprovoditi akciono istraživanje nameće se pitanje uloge deteta kao učesnika. U ovom slučaju akciona istraživanja se uglavnom sprovode u okruženju koja su bliska deci, koje deca poznaju (vrtić, vaspitna grupa i sl.). Takođe posmatranje i organizovanje aktivnosti u ovakvim okolnostima donekle zahtevaju od istraživača da posmatra pojave i fenomene uzimajući u obzir perspektivu dece. I iz takvih situacija odrasli uče, odnosno pokušavaju da razumeju situacije i određene pojave (Emond 2006). Često se otvara dilema koliko deca na ranom uzrastu mogu biti akteri participativnih akcionih istraživanja? Vranješević (2015) naglašava važnost i mogućnosti dece kao ko-istraživača gde se ističe da i deca na ranom uzrastu mogu da govore o svom iskustvu u vrtiću ili kod kuće ili da na neki način izraze svoje doživljaje (kroz crteže, priče, igru i sl.). Uloga praktičara, istraživača je da pažljivo sluša i posmatra decu i da kroz princip refleksivnosti pokuša da razume perspektivu deteta i da kroz razgovor zajedno sa decom dođu do zajedničkog tumačenja dečjeg iskustva (Vranješević 2015). To podrazumeva izmeštanje odraslog iz sveta uvreženih vrednosti i stavova koji mogu da utiču na sam tok istraživanja, na tumačenje rezultata, samu metodologiju dolaženja do odgovora. Takođe se smatra važnim u samom istraživanju uvažavanje kompetencija deteta koje treba da postanu važan deo metodologije u procesu istraživanja (Woodhead \& Faulkner 2008).

Posmatrajući akciona istraživanja u funkciji menjanja i unapređivanja vaspitne prakse potreba istraživača je usmerena na njeno razumevanje i nalaženje načina da se poboljša racionalnost i opravdanost aktivnosti i promena koje se uvode. Sagledavajući različta određenja ove vrste istraživanja u funkciji unapređivanja prakse može se istaći participatorska, saradnička i samorefleksivna priroda akcionog istraživanja. Ova istraživanja polaze od realnih fenomena u praksi koji su utemeljeni na životnom i praktičnom iskustvu, razvoj se temelji na zajednikom radu kroz parnerstvo, zajedno sa akterima vaspitnog procesa što doprinosi razvijanju novih načina posmatranja i interpretiranja realnosti kao i rezultata koji su pozitivni ishodi kao trag procesa istraživanja (Bredbury i Reason 2003).

\section{Unapređivanje predškolske ustanove kroz akciono istraživanje}

Specifičnost $u$ istraživanjima praktičara jest da se oni aktivno odnose prema saznanjima, prema primjeni postojećih i prema sticanju novih saznanja. U predškolskim ustanovama se mogu uspešno sprovoditi akciona istraživanja. Mnogi aktuelni problemi, svojstveni neposrednim situacijama u radu vaspitača mogu postati problemi i istraživačka pitanja koja praktičari rješavaju, is- 
tražuju, uvode novine i prate promene. Analizirajući literaturu koja na različite načine objašnjava i razmatra pristupe akcionim istraživanjima u praksi, malo je onih koji se konkretno bave njihovom primenom u predškolskim ustanovama. Uglavnom se praktična primena vezuje za školu i ulogu ovih istraživanja u njenom menjanju i razvoju (Harris 2002; Hopkins 2001; Kundačina i Banđur 2004; Stoll i Fink 2000). Međutim, potreba savremenog vrtića podrazumeva menjanje i razvoj ustanove polazeći od realnih potreba i okolnosti u kojima ta ustanova funkcioniše. Ostvarivanje unapređivanja uglavnom zavisi od potencijala u samoj ustanovi koji će stvarati pogodne uslove za promene. U takvim uslovima razvija se podsticajna atmosfera učenja, razvoja i vaspitanja dece i međusobna pomoć u tome.

Neka iskustva u svetu koja su proistekla iz realizacije projekata unapređivanja vaspitno-obrazovnih ustanova mogu se primeniti i u razvoju predškolskih. Kao ključne stavke izdvajaju se sledeće, koje smo prilagodili predškolskoj ustanovi a koje je istakao Haris, oslanjajući se na školu (Harris 2002): bitno za razvoj predškolske ustanove je stvaranje zajedničke vizije svih koji su uključeni u vaspitni proces; uvođenje promena na svim nivoima - od ustanove, preko vaspitne grupe do promena u profesionalnom razvoju vaspitača; podsticanje istraživanja vaspitača i njihov refleksivni pristup praksi koji kada postane svakodnevna profesionalna rutina doprinosi kvalitetu vaspitnih procesa koji se realizuju.

Akciona istraživanja se mogu koristiti kao deo nastojanja da predškolska ustanova i njeni akteri preuzmu aktivnu ulogu u ostvarivanju promena i razvoja. Teoretičari navode da akciona istraživanja uvek treba započeti pitanjem koje je usmereno na unapređivnje prakse, na razumevanje te prakse i na širu vaspitno-obrazovnu situaciju (McNiff i Whitehead 2002). Neka od tih pitanja mogu biti:

- Kako podsticati kreativnu komunikaciju među decom?

- Kako podsticati saradnju i solidarnost među decom?

- Kako ostvariti interakciju dece različitog uzrasta u ustanovi?

- Kako učiniti situacije za igru i učenje podsticajnim za istraživanje dece, rešavanje problema i slično?

- Kako poboljšati organizacione uslove u grupi?

- Kako funkcionalno primeniti digitalnu tehnologiju u radu sa decom?

- Kako unaprediti stručno usavršavanje vaspitača u okviru predškolske ustanove?

- Kako unaprediti saradnju vaspitača i roditelja i uključiti ih više u rad predškolske ustanove? 
Planiranje procesa koji će na kraju dovesti do kvalitativnih odgovora na postavljena istraživačka pitanja podrazumeva postavljanje akcionog plana koji bi trebao da ima određenu strukturu od pitanja: šta je predmet mog interesa, preko pitanja koja se odnose na motiv zainteresovanosti za konkretan problem, realnih mogućnosti za preduzimanje određenih aktivnosti i njihovo preciziranje vremenski i organizaciono, preko pitanja kako će se prikupiti dokazi koji će pokazati da se uticalo na situaciju i kako će se osigurati prihvatljivost $\mathrm{i}$ istinitost procena efekata i promena koje su se desile. Akciona istraživanja podrazumevaju krug planiranja, akcija, praćenja i posmatranja, kao i refleksije. Markovic (Markowitz 2011) navodi da je na početku istraživanja potrebno da svaki istraživač utvrdi svoj plan istraživanja i jasno definiše vrednosti od kojih polazi u vaspitnom delovanju. Prispitivanje vaspitne prakse vaspitačima pomaže da objasne svoja verovanja i stavove i time utvrđuju da li ih je potrebno poboljšati i unaprediti. Oni vaspitači koji vaspitne situacije promišljaju na nov način, koji identifikuju probleme u vaspitnoj sredini su refleksivni praktičari. $U$ takvim sitauacijama oni samokritički pristupaju situacijama, promišljaju svoje aktivnosti i delovanja, prikupljaju podatke o tome analiziraju ih i dolaze do nekih saznanja. Istraživanja vaspitača i saradnika u predškolskoj ustanovi podrazumevaju proučavanje vaspitnih fenomena, a to zahteva određen nivo profesionalnosti i spremnosti da unapređuju svoj rad.

Kako se akciona istraživanja najpre odnose na ličnu praksu i unapređenje, malo je objavljenih rezultata ovih istraživanja u stručnoj i naučnoj literaturi. Kao primere sprovedenih akcionih istraživanja u oblasti predškolskog vaspitanja prikazaćemo rezultate nakoliko istraživanja koji su objavljeni. Istraživanja su predmetno usmerena na decu i na vaspitače. Jedno od istraživanja sprovedeno je u Sigapuru u nekoliko prigradskih vrtića, gde je akcenat na uvođenju aktivnosti koje bi pomogle deci predškolskog uzrasta da se lakše adaptiraju na nove uslove u daljem vaspitanju i obrazovanju. Efekti aktivnosti su se reflektovale na pozitivne stavove predškolske dece prema školi i kasnije smanjenje stresa i anksioznosti u prvim danima škole (Lee i Goh 2012). Rezultati još jednog objavljenog istraživanja su usmerena na decu predškolskog uzrasta i govore o primeni video snimanja komunikacije trogodišnje dece u predškolskoj igri i mogućnost kroz analizu kombinovanja vizuelnog, auditivnog i pisanog materijala (dnevnici beleženja) dolaženja do saznanja o načinima unapređivanja i razvijanja komunikacije te dece (Flewitt 2006). Prikazana istraživanja govore da se unapređivanje prakse u konkretnim aktivnostima može ostvariti kroz akciona istraživanja i refleksiju vaspitača.

Takođe, predmet akcionih istraživanja može biti usmeren i na same vaspitače u funkciji njihovog profesionalnog razvoja. O tome govore rezultati sle- 
dećih istraživanja. Jedno je sprovedeno u vrtiću u severnoj Grčkoj. Izvršena je implementacija procesa interne evaluacije u vrtiću, a rezultati su pokazali da su uvedene aktivnosti pomogle vaspitačima da prevaziđu svoje predrasude o evaluaciji kao kontroli prakse i da iskoriste prednosti evaluacije za refleksiju u svom radu i time poboljšaju vaspitne procese (Galini i Efthymia 2010). Stojanović (2011) je sproveo istraživanje o značaju samorefleksivnosti vaspitača, a ipitivano je kako vaspitači procenjuju odnos samorefleksivnosti i metodičkih inovacija. Rezultati su pokazali da vaspitači kod kojih je razvijena svest i sposobnost samorefleksije u značajnoj meri primenjuju metodička rešenja koja apostrofira savremena predškolska pedagogija. Takođe je zaključeno da je samorefleksivnost vaspitača (promišljanje o metodičkim rešenjima koja se primenjuju, sagledavanje rezultata, svest o svojim stavovima, sistemu vrednosti, pedagoškom stilu, kritičko procenjivanje stila komunikacije s decom, njihovim roditeljima i kolegama itd.) značajno povezana sa metodičkim rešenjima u vrtiću koja se smatraju savremenim (Stojanović 2011). Istraživački rad vapitača i njihova uloga kao refleksivnih praktičara u vaspitnom procesu zahteva različite preduslove i okolnosti, od bazičnog obrazovanja i razvijanja istraživačkih i refleksivnih kompetencija, do uslova u samoj ustanovi u kojima vaspitači rade (organizacija rada, sredstva, kolegijalna i profesionalna podrška i sl.). Jedan od uslova je njihova kompetentnost za unapređivanje prakse, njeno istraživanje i kritičko-refleksivni pristup.

\section{Kompetencije vaspitača za istraživanje prakse}

Potreba savremene predškolske prakse nameću vaspitačima ulogu samostalnog istraživača, a ne samo učesnika $u$ istraživanjima vaspitne prakse. Kompetentnost vaspitača je rezultat kontinuiranog učenja u toku bazičnog obrazovanja, a naročito u toku profesionalnog rada u praksi. Kompetentnost podrazumeva znanja, umenja, stavove i vrednosti profesionalca koja se stalno menjaju, nadograđuju, unapređuju. Definisan okvir kompetencija vaspitača je često nastaje kao potreba funkcionisanja sistema vaspitanja i obrazovanja i u funkciji je obezbeđivanja kvaliteta predškolskog vaspitanja. Metodološka kompetentnost vaspitača za primenu akcionog istraživanja pretpostavlja potrebu drugačijeg promišljanja osnovnih pedagoških fenomena kao i inovativni i permanentni refleksivni pristup vaspitnom procesu u praksi i promenama. Kompetentnost vaspitača se može razvijati kroz istraživanje sopstvene prakse, profesionalno umrežavanje, razvojne projekte, sardničke aktivnosti u praksi svog delovanja (Pavlović Breneselović i Krnjaja 2012). Polazeći od definisanih kompetencija vaspitača Pravilnikom o standardima kompetencija za profesiju vaspitač u Republici Srbiji, prepoznajemo definisana znanja i umenja koja su neophodna za realizaciju akcionih istraživanja. Precizirano je da 
vaspitač treba da razvija projekte zasnovane na učenju kroz istraživanje, razmenu i saradnju sa decom; da razvija pedagoška znanja preispitivanjem reorije i prakse kroz praćenje i slušanje dece i konsultovanje sa njima; da sarađuje sa kolegama u razmeni iskustava, zajedničkom učenju i istraživanju; da preuzima inicijativu i vodi aktivnosti tima i proces razvoja dečjeg vrtića; da kritički sagledava i razvija svoju praksu kroz vlastita istraživanja i samorefleksiju (Pravilnik o standardima kompetencija za profesiju vaspitač i njegovog profesionalnog razvoja 2018).

Navedina umenja od vaspitača traže da on mora biti praktičar i teoretičar prakse koji je orijentisan na permanentno obrazovanje. On mora biti aktivni pojedinac koji je spreman da preispituje vlastito mišljenje, da istražuje mogućnosti i različite načine delovanja kako bi pronašao odgovor na praktične probleme (Maksimović i Banđur 2013). Otežavajuće okolnosti za realizaciju ovih kompetencija ugalvnom se pronalaze u nedovoljnoj stručno-metodološkoj osposobljenosti vaspitača ili nastavnika (Kundačina i Banđur 2004; Maksimović 2012; Stamatović 2015). Ono što nedostaje u metodološkom obrazovanju vaspitača u okviru fakulteta jeste segment praktične obuke za samostalna istraživanja, jer se teorija i praktični pristup istraživanju ne povezuje. Zaključak koji navodi Stojanović (2011) u svom istraživanju odnosi se na preporuku da u okviru obrazovanja vaspitača se mora težiti formiranju refleksivnih praktičara čija će refleksija biti dobro teorijski zasnovana i kojima će evaluacija i samoevaluacija biti sastavni deo svakodnevne prakse. Dalje usavršavanje vaspitača u toku profesionalnog rada takođe ne nudi vezu istraživanja i prakse u dovoljnoj meri kroz različite oblike i načine usavršavanja. Vaspitna ustanova mora postati mesto učenja i usavršavanja i podsticajna sredina za razvoj profesionalnosti vaspitača gde vaspitači stalno uče kroz zajedničko učešće sa decom, kolegama i roditeljima i u tom procesu definišu probleme vlastite prakse težeći da je unapređuje, traže odgovore na pitanja i preispitivanja sebe šta znači biti dobar vaspitač.

Često je u vrtićima realizacija akcionih istraživanja ili refleksivni pristup praksi stvar entuzijazma pojedinaca, koji se najčešće suočavaju sa problemima realizacije ili nemaju dovoljnu podršku od strane svojih kolega ili rukovodstva ustanove. Popularizaciju ove vrste istraživanja mogu doprineti pozitivni rezultati koji dovode do promena i pokazuju neku vrednost koja je važna ne samo za pojedinca već i za ostale učesnike.

\section{Zaključak}

Doprinos akcionog istraživanja u predškolskom vaspitanju može se posmatrati u pravcu razvoja predškolskih ustanova i vaspitne prakse i u pravcu profesionalnog razvoja vaspitača. $U$ kontekstu razvoja predškolske ustanove 
značaj se vidi u mogućnostima donošenja odluka na nivou ustanove gde je odgovornost za planiranje razvoja i unapređivanja na samoj ustanovi i zaposlenima u njoj. Postavljanje akcionog istraživanja u fokus razvoja prakse podrazumeva biranje problema istraživanja u skladu sa potrebama ustanove, vaspitne grupe ili pojedinca. $U$ toku istraživanja prikupljaju se podaci da bi se otkrio problem, traga se za rešenjima, preduzimaju se akcije i prati se uspešnost dolaska do rešenja problema. Istraživački cikluse se mogu ponavljati dak se ne nađe zadovoljavajuće rešenje. $U$ tom procesu mogu se javiti i neka nova istraživačka pitanja koja usmeravaju istraživanja u drugom pravcu.

Jasno je da akciona istraživanja jesu korisna i vaspitačima. Kao način usavršavanja i dolaženja do novih saznanja otvaraju vidike, menjaju njihov sistem vrednosti i uverenja, doprinose razvoju lične vrednosti i samopoštovanja. Kroz rezultate istraživanja dolazi se do usklađivnja teorijskih znanja i prakse, mnogo se bolje razumeju teorijska znanja kao polazišta istraživačke prakse. Akciona istraživanja razvijaju i podstiču sposobnosti refleksije i šire perspektive sagledavanja problemskih fenomena u praksi.

\section{Bibliografija}

Bredbury, H., i P. Reason. 2003. »Action Research: An Oportunity for Revitalision Research Purpose and Practices." Qualitative Social Work 2 (2): 155-175.

Bognar, B. 2006. »Akcijska istraživanja u školi.» Odgojne znanosti 8 (1): 209-228. - 2009. „Ostvarivanje suštinskih promjena u odgojnoj praksi posredstvom akcijskih istraživanja." Odgojne znanosti 11 (2): 147-163.

Emond, R. 2006. »Ethnographic Research Methods with Children and Young People." U Researching Children's Experience: Approaches and Methods, ur. S. Greene i D. Hogan, 123-140. London: Sage.

Flewitt, R. 2006. »Using Video to Investigate Preschool Classroom Interaction: Education Research Assumptions and Methodological Practices.« Visual Comunication 5 (1): 25-50.

Galini, R., i P. Efthymia. 2010. »A Collaborative Action Research Project in the Kindergarten: Perspectives and Challenges for Teacher Development through Internal Evaluation Processes."New Horizons in Education 58 (2): 18-33.

Gojkov, G. 2007. Kvalitativna istraživačka paradigma u pedagogiji. Vršac: Visoka škola strukovnih studija za obrazovanje vaspitača.

Harris, A. 2002. School Improvement: What's in it for Schools? London: Routledge. Hopkins, D. 2011. School Improvement for Real. London: RoutiedgeFalmer.

Korthagen, F. A. J. 2011. »Making Techer Education Relevant for Practice: The Pedagogy of Realistic Teacher Education. «Orbis Scholae 5 (2): 31-50.

Kundačina, M., i V. Banđur. 2004. Akciona istraživanja u školi (nastavnici kao istraživači). Užice: Učiteljski fakultet u Užicu. 
Lankshear, C., i M. Knobel. 2004. A Handbook for Teacher Research: From Design to Implementation. Minton Keynes: Open University Press.

Lee, S., i G. Goh. 2012. "Action Research to Address the Transition from Kindergarten to Primary School: Children's Authentic Learning, Construction Play, and Pretend Play.« Early Childhood Research \& Practice 14 (1): 26-38.

Maksimović, J. 2010. »Elementi i postulate akcionih istraživanja u pedagogiji.» Radovi filozofskog fakulteta 12 (2): 189-198.

—. 2012. Akciona istraživanja u pedagoškoj teoriji i praksi. Niš: Filozofski fakultet.

Maksimović, J., i V Banđur. 2013. „Savremena akciona istraživanja i metodološkqa obrazovanost nastavnika refleksivnog praktičara.« Teme 37 (2): 595610.

Markowitz, A. 2011. »Akcijska istraživanja učitelja u nastavi: drugačiji pogled.» U Akcijsko istraživanje i profesionalni razvoj učitelja i nastavnika, ur. M. Mićanović, 11-27. Zagreb: AZOO.

McNiff, J., i J. Whitehead. 2006. Action Research: Living Theory. London: Sage.

Pavlović Breneselović, D., i Ž. Krnjaja. 2012. »Sistemski pristup profesionalnom usavršavanju vaspitača.« Andragoške studije 2:143-161.

Park, P. 1999. »People Knowledge and Change in Participatory Research.« Management Learning 30 (2): 141-157.

Petrović, D. 2008. »Akciono istraživanje: neka teorijska i praktična pitanja.«U Metateorijske osnove kvalitativnih istraživanja, ur. D. Stojnov, 237-275. Beograd: Zepter Bookworld.

Pešić, M. 2004. Pedagogija u akciji: metodološki priručnik. Beograd: Institut za pedagogiju i andragogiju Filozofskog fakulteta u Beogradu.

Pravilnik o standardima kompetencija za profesiju vaspitač i njegovog profesionalnog razvoja. 2018. Službeni glasnik Republike Srbije: Prosvetni glasnik, br. 16.

Stamatović, J. 2015. Kvalitet i samovrednovanje rada nastavnika. Beograd: Institut za pedagogiju i andragogiju Filozofskog fakulteta.

Stojanović, A. 2011. "Samorefleksivnost vaspitača kao determinanta metodičkih inovacija u predškolskom vaspitanju. «Inovacije u nastavi 24 (3): 114-121.

Stoll, L., i D. Fink. 2000. Mijenjajmo naše škole. Zagreb: Educa.

Vranješević, J. 2015. »Deca kao (ko)istraivači: participativna istraživanja i najbolji interes deteta.«Primenjena psihologija 8 (2): 187-202.

Woodhead, M., i D. Faulkner. 2008. "Subjects, Objects or Participants? Dilemas of Psychological Research with Children.« U Research with Children, ur. P. Christensen i A. James, 10-39. London: Routledge.

\section{Akcijsko raziskovanje in predšolska vzgoja}

Raziskovanje v izobraževanju je zelo široko in raznoliko področje. Zaradi tega so se razvila posamezna podpodročja raziskovanja v izobraževanju, ki se os- 
redotočajo samo na določena področja znotraj izobraževanja. Eno od podpodročij je raziskovanje zgodnjega otroštva, ki se je pod vplivom anglosaške tradicije raziskovanja premaknilo od tradicionalnega pozitivističnega $\mathrm{k}$ bolj konstruktivističnemu pristopu. $V$ članku izpostavljamo posebnosti raziskovanja zgodnjega otroštva in obravnavamo etiko ter pristope $\mathrm{k}$ raziskovanju in načine zbiranja podatkov pri raziskovanju zgodnjega otroštva.

Keywords: raziskovanje v izobraževanju, zgodnje otroštvo, etika, raziskovalne metode 